\title{
Fiscaoeconomia
}

E-ISSN: 2564-7504

2021, Volume 5, Issue 3, 978-989

https://dergipark.org.tr/tr/pub/fsecon

\section{The Determinants of Rural Households' Income in Nigeria}

\section{Ridwan MUKAILA ${ }^{1}$, Abraham FALOLA ${ }^{2}$, Lynda Ogechi EGWUE ${ }^{3}$}

\begin{abstract}
Most rural areas in developing nations were faced with the problem of a high poverty rate. A better understanding of drivers of rural household income is a powerful guide for proper intervention towards poverty alleviation and better wellbeing. This study, therefore, investigates the drivers of rural households' income in Nigeria. Data sourced from the National Bureau of Statistics were analysed using descriptive statistics and multiple regression. The results revealed that the majority of rural households' heads were males who were married with an average household size of 6 persons and a high dependency ratio (0.94). The majority had a low level of education, depends on agricultural activities and earned a monthly income of N42,142.70. Gender of household's head, household size and years of education were the significant factors enhancing rural households' income while dependency ratio was the factor inhibiting rural households' income. Thus, rural education and women empowerment is needed to boost rural income.
\end{abstract}

Jel Codes: D31, D33, P25.

Keywords: Developing countries; Income; High poverty rate; Nigeria; Rural households.

\section{Introduction}

One of the major problems facing the world today is the high rate of poverty with its widest concentration in developing countries, most especially sub-Sahara Africa. More than 80 per cent of extremely poor people globally reside in rural areas with the majority in developing countries (De La O Campos et al., 2018). About 413 million people were extremely poor in subSahara Africa accounting for 41 per cent of the total population (World Bank, 2018; Beegle and Christiaensen, 2019). It was estimated that about 9 persons out of every 10 people in extreme poverty will be from sub-Saharan Africa by 2030 (World Bank, 2018). According to the National Bureau of Statistics (2020), 40.1 percent of the Nigerian population are poor and

\footnotetext{
${ }^{1}$ Department of Agricultural Economics, University of Nigeria, Nsukka, Enugu State, Nigeria, Email: ridwan.mukaila@unn.edu.ng, ORCID: 0000-0001-8584-0858

2 Department of Agricultural Economics and Farm Management, University of Ilorin, Ilorin, Kwara State, Nigeria, Email: falola.a@unilorin.edu.ng, ORCID: 0000-0002-5265-9355

${ }^{3}$ Department of Agricultural Economics, University of Nigeria, Nsukka, Enugu State, Nigeria, Email: ogechi.egwue@unn.edu.ng, ORCID: 0000-0002-2390-9220
}

Citation/Atıf: Mukaila, R.; Falola, A.; Egwue, L. O. (2021). The Determinants of Rural Households' Income in Nigeria. Fiscaoeconomia, 5(3), 978-989. Doi: 10.25295/fsecon.974485 
Mukaila, R.; Falola, A.; Egwue, L. O. (2021). The Determinants of Rural Households' Income in Nigeria. Fiscaoeconomia, 5(3), 978-989. Doi: 10.25295/fsecon.974485

70 per cent of these reside in rural areas. The above statistics show that rural households are the most hit in terms of poverty in sub-Sahara Africa including Nigeria and other developing nations.

Despite government efforts through several programs to reduce poverty in Nigeria, poverty remains a major challenge, especially in rural areas. This is not only true in Nigeria but across sub-Saharan Africa. Rural households are predisposed to hunger, want, deprivation, disease and premature death as a result of the high level of poverty (Fadipe et al., 2014). Also, the high poverty rate affects the education system, wellbeing and standard of living of rural people in most developing countries. A continuous low income and high poverty rate could lead to a high crime rate in the society, risk in life and property, child abuse, emotional and behavioural problems among both children and adults. This calls for more urgent attention and intervention both nationally and globally to avoid serious consequences.

According to kryszak and Matuszczak (2019), the income of people living in a country is the criteria to assess the extent of socio-economic development in such a nation. Furthermore, the income of people determined their purchasing power, level and pattern of consumption, wealth in terms of asset and their wellbeing. Therefore, a better understanding of factors inhibiting or enhancing rural household income is a powerful guide for proper intervention and implementation of policies geared towards poverty alleviation, increase rural household income and a better standard of living of rural households globally, especially in developing countries, and most especially sub-Sahara Africa including Nigeria.

Previous studies on the determinants of rural income in Nigeria (e.g., Mafimisebi, 2008; Kwaghe et al., 2009; Fadipe et al., 2014) focused on a particular group and small location, thus did not cover the entire country. Meanwhile, there is a need to carry out a national study that will give a better understanding and representation of the rural areas in the country. The result of such research would also be of importance to other developing nations that are homogeneous to Nigeria. Because of this, this study was carried out to investigate the factors influencing rural household income in Nigeria using General Household Survey data. This study contributes to a better understanding of the determinants of rural household income across the country (Nigeria) as it covered the entire rural areas of the country. The findings from the study will guide the government and policymakers on eradicating extreme poverty, improving the rural households' income, livelihood and better their wellbeing.

This paper has five sections, the subsequent section reviewed relevant literature, section 3 described the study area and data, it further explained the methods used in this research. Section 4 dealt with results and discussion of the research and the last section concludes the study with policy recommendations.

\section{Literature review}

Different methods and data set have been used by researchers to investigate the determinants of income. In the study of Safa (2005) on the socioeconomic factors influencing the small-scale agroforestry farmers income in Yemen, the study used weighted least square and ordinary least square regression. The result showed that the education level of household head, family size, livestock holding, area of land and whether coffee is grown were the significant factor influencing farmers' income. Mafimisebi (2008) investigated the 
Mukaila, R.; Falola, A.; Egwue, L. O. (2021). The Determinants of Rural Households' Income in Nigeria. Fiscaoeconomia, 5(3), 978-989. Doi: 10.25295/fsecon.974485

determinants of farm income among cassava farmers in Ondo State, Nigeria using multiple regression. The result revealed that the variety of cassava cultivated, farm size, expense on sales of cassava farm and amount of hired labour were the significant factors influencing cassava farmers income. Kwaghe et al. (2009) investigated the factors influencing cowpea farmers income in Bama local government area, Borno State, Nigeria. They employed multiple regression to identify the income determinant and found out that education of household heads, years of farming experience, access to extension services, number of productive members per household were the factors influencing cowpea farmer income positively.

Swindall et al. (2011) investigated the drivers of income from self-employed in South Carolina. The study used an ordinary and quantile regression to identify the drivers of self-employed income. They reported that educational status, sex and percentage of self-employed income to total family income are significant factors influencing self-employed income. Nzabakenga et al. (2013) examined the drivers of farm income among smallholder farmers of the Northern part of Burundi using linear regression. Their result revealed that family size and farm size were the significant factors affecting smallholder farmers' income positively. In the same vein, Fadipe et al. (2014) analysed the drivers of income among rural households in Kwara State, Nigeria using ordinary least squares. The result revealed that the educational level of household head, gender, access to electricity and farm size were the major determinants of household income. Urgessa (2015) examined the determinants of rural households' income in Ethiopia using two rounds of panel data. The author investigated the change in income per capita per household using the fixed effect before examining the determinants of rural households using two stages least square. The result revealed that gender of household head, non-farm income, number of livestock owned, farmland productivity and labour productivity positively influenced household's income. While number of dependant household members negatively influenced household income.

Viera et al. (2017) examined the factor affecting the income of peach farmers in the Province of Tungurahua, Ecuador using OLS. The findings revealed that the use of chemicals in production and sown area influenced peach farmers income positively. While farmers age and production issue negatively influenced their income. Purnamadewi and Firdaus (2018) examined the determinant of income among farm households in the Malang district of Indonesia. They employed multiple regression to identify the significant factors influencing a household's income. Their result revealed that household head educational status, number of labours, household size, agroforestry land size, farm size, livestock ownership, access to credit and cropping patterns were the determinants of income.

Anang and Yeboah (2019) investigated the off-farm income determinants among smallholder rice farmers in Northern Ghana. The authors identified the drivers of off-farm work and factors affecting the off-farm income of farmers using the double hurdle model. The results revealed that geographical location, years of education, and farming experience are the factors influencing off-farm income. Kryszak and Matuszczak (2019) also examined the factors influencing farm income in the EU new member and old member states. The study covered the periods of 2004 to 2017 and was analysed using the quantile panel regression model and basis panel regression model. Their study revealed that farm income in new EU member states was more sensitive to capital expenditure, direct payment and growing specialization, 
Mukaila, R.; Falola, A.; Egwue, L. O. (2021). The Determinants of Rural Households' Income in Nigeria. Fiscaoeconomia, 5(3), 978-989. Doi: 10.25295/fsecon.974485

while there was a high elasticity of income as a result of labour factors in the old EU member states. On the other hand, the level of financial leverage affects income negatively. The authors further stated that as farm income increases, the influence of land and labour factors decreases while the capital factors remain unchanged. Ryś-jurek (2019) investigated the factors influencing family farm income in the European Union (EU) using data from the Farm Accountancy Data Network from 2004 to 2017. The study employed the fixed and random effect model to identified the income determinants. Their results revealed that utilised agricultural area, cash flow, net investment per hectare, subsidies, the share of livestock and crop production in total production had a positive influence on family farm income. While inputs per hectare affect family farm income negatively.

\section{Materials and Methods}

\subsection{Study area}

The study location is Nigeria. The country is one of the sub-Sahara African countries located in West Africa and lies between longitudes $3^{\circ}$ and $14^{\circ}$ East and latitudes $4^{\circ}$ and $14^{\circ}$ North. Nigeria has a landmass of 923,768 sq. km and a population of 202 million (World Bank, 2019). The population of Nigeria is slightly above 50 per cent of the total population of West Africa which makes it the most populous country in Africa. The rural areas of the country engaged in agricultural activities as their major source of income and livelihood. There are also people who are engaged in some other professions such as artisan, business and civil servant in the country, though they are the minority of the population in rural areas.

\subsection{Data}

This study utilized secondary data from the third wave of the General Household Survey (GHS) Panel gotten from the National Bureau of Statistics. The GHS is a report by the NBS in collaboration with the Federal Ministry of Agriculture and Rural Development and the World Bank Living Standards Measurement Study (LSMS). From the data sourced from the National Bureau of Statistics, 3112 rural households across all the regions in Nigeria were used for this study. This thus gave a better representation of rural households in the country. Table 1 presents the distribution of the surveyed Nigeria rural households by region.

Table 1. Distribution of Rural Households Surveyed by Region

\begin{tabular}{|l|l|l|}
\hline Region & Frequency & Percentage \\
\hline North-Central & 567 & 18.22 \\
\hline North-East & 538 & 17.29 \\
\hline North-West & 721 & 23.17 \\
\hline South-East & 560 & 17.99 \\
\hline South-South & 511 & 16.42 \\
\hline South-West & 215 & 6.91 \\
\hline Total & 3112 & 100 \\
\hline
\end{tabular}

Source: Computed by the authors from the General Household Survey data. 
Mukaila, R.; Falola, A.; Egwue, L. O. (2021). The Determinants of Rural Households' Income in Nigeria. Fiscaoeconomia, 5(3), 978-989. Doi: 10.25295/fsecon.974485

\subsection{Data Analysis}

To achieve the objectives of this study, descriptive statistics such as mean, frequency and percentage were used to profile the socioeconomic characteristics of rural households in Nigeria. While tables were used to present the results of this study.

This study also adopted a multiple regression model to determine the effect of selected socioeconomic variables on income distribution in rural Nigeria. Multiple regression is an extension of linear regression which is used in predicting a scalar response variable by two or more explanatory variables. This model was used because the dependent variable (household income) is a continuous variable and six explanatory variables were used to predict its outcome. The multiple regression model has been used in previous studies such as Purnamadewi and Firdaus (2018); Fadipe et al. (2014); Nzabakenga et al. (2013) in examining the factors influencing income.

The multiple regression model is specified explicitly in the linear form as:

$I N C_{i}=\beta_{0}+\beta_{1} A G E+\beta_{2} G E N+\beta_{3} E D U+\beta_{4} H H S+\beta_{5} M A R+\beta_{6} D E P+\varepsilon_{i}$

Where,

INC is the annual income of rural households in Naira

AGE is the age of rural household heads in years

GEN is the gender of rural household head ( male $=1$, female $=0$ )

EDU is the years of education

HHS is the rural household size (number of people living in a household)

MAR is the marital status of rural household head (married $=1$, otherwise $=0$ )

DEP is the dependency ratio (number of people depending on household head)

$\varepsilon_{i}$ is the error term or disturbance term.

\section{Results and Discussion}

\subsection{Socioeconomic Profile of Rural Households in Nigeria}

Socioeconomic features of households are very important in interventions and formulating policy regarding livelihood, the standard of living and the wellbeing of people. Because of this, the study explored the rural households' socioeconomic profile. The results presented in Table $2 a$ revealed that the majority of the rural households' heads were males. This is not surprising as men are decision-makers in the family in most African countries especially in the rural areas. Also, they provide for the needs of their households and are responsible for their welfare. Regarding the marital status of rural household's heads, the majority (84.7\%) were married. About 10 percent of the respondents have never married while a few were divorced $(0.3 \%)$ and separated $(0.5 \%)$. There was more widow (7.8\%) than widower (0.8) in rural areas (Table 2). This could be as a result of physical and mental stress imposed on most males who headed households in rural households. Considering that most rural households engaged in farming activities that required physical strength and most of the energy required are provided by males. This imposed the male to physical stress which may lead to poor health at an older age and the death of male household heads in rural areas. 
Mukaila, R.; Falola, A.; Egwue, L. O. (2021). The Determinants of Rural Households' Income in Nigeria. Fiscaoeconomia, 5(3), 978-989. Doi: 10.25295/fsecon.974485

Regarding their educational status, the majority (77.8\%) of the rural households' heads spent between 11 and 16 years in school. On average, rural households spent about 11 years in school. This suggests that the majority did not have above secondary school education. This implies a low level of education in rural areas compared to the urban areas in Nigeria where many people have tertiary education. The level of education plays a significant role in the life of people including rural dwellers, it helps them to make a better decision relating to best farming practices, adoption of innovation, when to invest, where to invest and level of investments. It also enhances their access to relevant information. Adequate information and their usage through the high level of education will, in turn, increase their income. As it was reported to influence income positively (Xiong and Niu, 2010).

Regarding rural household heads source of income, agricultural and allied activities played a significant role in most rural households as the majority (48.5\%) of the rural household heads in Nigeria sourced their income from agricultural and allied activities. This implies that agriculture is widely practised in rural areas in Nigeria and it is the major source of livelihood to many rural households. A significant percentage $(33.8 \%)$ of the household heads were artisans and a few were salary earners (8.6\% works in the private sector while $9.5 \%$ works in the public sector). The majority (55\%) of the rural households' heads earn a monthly income equal to or less than $\$ 10,000$ (USD 25.84) which was lower than the minimum wage of $\$ 30,000$ (USD 77.51) in Nigeria. This implies a low monthly income among the majority of the rural households' heads. A significant proportion (39.7\%) of rural households' heads earned between $\$ 10,001$ and $\$ 60,000$ monthly while a few of them earned $\$ 60,001$ (USD 155.02) to $\$ 100,000$ (USD 258.37) and above $\$ 1000,000$ (USD 258.37). The results suggest a wide variation in the income distribution of rural households. The rural households had an average monthly income and average monthly per capita income of $\$ 42,142.70$ (USD 108.61) and \#7,023.72 (USD 18.10), respectively.

Table 2a. Distribution of Rural Households by Gender, Marital status, Education and Income

\begin{tabular}{|l|l|l|l|l|}
\hline Variables & Categories & Frequency & Percentage & Mean \\
\hline Gender & Male & 2514 & 80.8 & \\
\hline & Female & 598 & 19.2 & \\
\hline Marital status & Married & 2637 & 84.7 & \\
\hline & Never married & 318 & 10.2 & \\
\hline & Divorced & 8 & 0.3 & \\
\hline & Separated & 16 & 0.5 & \\
\hline & Widower & 12 & 0.8 & \\
\hline Education (years) & Widow & 121 & 7.8 & \\
\hline & $6-11$ & 691 & 22.2 & 11.2 \\
\hline Source of income & $11-16$ & 2421 & 77.8 & \\
& $\begin{array}{l}\text { Agriculture } \\
\text { allied activities }\end{array}$ & 1509 & 48.5 & \\
\hline & Artisans & 1039 & 33.4 & \\
\hline & Private sector & 268 & 8.6 & \\
\hline & Public Sector & 296 & 9.5 & \\
\hline Monthly income (\#) & $\leq 10,000$ & 1711 & 55 & $42,142.70$ \\
\hline
\end{tabular}


Mukaila, R.; Falola, A.; Egwue, L. O. (2021). The Determinants of Rural Households' Income in Nigeria. Fiscaoeconomia, 5(3), 978-989. Doi: 10.25295/fsecon.974485

\begin{tabular}{|l|l|l|l|l|}
\hline & $10,001-60,000$ & 1236 & 39.7 & \\
\hline & $60,001-100,000$ & 85 & 2.7 & \\
\hline & $\geq 100,001$ & 80 & 2.6 & \\
\hline
\end{tabular}

Source: Computed by the authors from the General Household Survey data.

The average rural household size was 6 persons per household which were, however, larger than the average household size in urban areas (see Table $2 b$ ). This suggests a relatively large household in rural areas. The larger household size in rural areas is to have enough family size which can be used in farming activities as rural farmers tend to have many children to be used as family labour on the farm (Mukaila et al., 2020). This is in tandem with the findings of Usman et al. (2016) who reported a larger rural household size of six persons in Nigeria. The dependency ratio (0.94) in rural Nigeria was slightly higher than the dependency ratio in urban areas (0.78) of the country. This suggests a relatively high dependent population in rural households than urban households in Nigeria. The high dependency ratio among the rural households could put a financial burden on the household heads. This might, however, also trigger the probability of a high poverty rate among rural households. The age of rural households was grouped into the working population (15 to 64 years) and non-working population, that is, the dependent population which comprises children (people less than 15 years) and older people (those above 65 years). The results revealed that more than half (51.6\%) of the rural households' members fall within the working population group, out of which $24.7 \%$ were males while $26.9 \%$ were females (Table $2 b$ ). The children in rural households were $43.1 \%$ while older people were $5.3 \%$. This suggests a relatively large number of dependent populations in rural households which may inhibit the rural households' per capita income.

Table 2b. Distribution of Rural Households by Household Size and Percentage Distribution of Individuals by Sex and Age Group

\begin{tabular}{lllll}
\hline & Category & Rural & Urban & NGA \\
\hline $\begin{array}{l}\text { Average Household size } \\
\text { Dependency ratio }\end{array}$ & & 6 & 4.9 & 5.5 \\
Age & & 0.94 & 0.78 & 0.88 \\
$0-5$ & & & \\
& Male & $7.7 \%$ & $6.6 \%$ & $7.3 \%$ \\
$6-9$ & Female & $7.2 \%$ & $6.4 \%$ & $6.9 \%$ \\
& Male & $6.8 \%$ & $5.4 \%$ & $6.3 \%$ \\
$10-14$ & Female & $6.2 \%$ & $5.9 \%$ & $6.1 \%$ \\
& Male & $8.3 \%$ & $7.2 \%$ & $7.9 \%$ \\
$15-64$ & Female & $6.9 \%$ & $6.7 \%$ & $6.9 \%$ \\
& Male & $24.7 \%$ & $27.2 \%$ & $25.6 \%$ \\
$65+$ & Female & $26.9 \%$ & $29.1 \%$ & $27.7 \%$ \\
\multirow{2}{*}{ Total } & Male & $2.9 \%$ & $2.9 \%$ & $2.9 \%$ \\
& Female & $2.4 \%$ & $2.8 \%$ & $2.5 \%$ \\
& Male & $50.3 \%$ & $49.2 \%$ & $49.9 \%$ \\
\hline
\end{tabular}

Source: Computed by the authors from the General Household Survey data. 
Mukaila, R.; Falola, A.; Egwue, L. O. (2021). The Determinants of Rural Households' Income in Nigeria. Fiscaoeconomia, 5(3), 978-989. Doi: 10.25295/fsecon.974485

\subsection{The Determinants of Rural Households' Income}

Table 3 present the results of linear, semi-log and double log functional forms used to estimate the determinants of rural income. The linear regression gave the best result based on Rsquare, number of significant variables, expected sign of the variables, model f-statistic and probability level. The result of the multiple regression of the linear functional form revealed that the coefficient of multiple determination $\left(R^{2}\right)$ was 0.5213 implying that age, household size, dependency ratio, gender, years of education and marital status jointly explained $52.13 \%$ of the variation in household income (Table 3). It can therefore be concluded that the independent variables significantly affect household income. The F-ratio value (17.335) was however significant at a $1 \%$ level of significance. This suggests that the model has a good fit. Furthermore, the model passed the heteroskedasticity test. The dependency ratio, gender of household heads, household size and level of education were the significant factors influencing rural household income.

The dependency ratio was negatively related to household income and significant at $1 \%$ level meaning that household income decrease as the dependency ratio increases. This is because the dependent population did not add any financial benefit to the household rather take from the household thereby reducing the income available in the household. The dependent population further reduced the per capita income in households. This is in line with the findings of Urgessa (2015) who reported that the number of dependent household members negatively influenced household income.

Gender of household head was positively related to household income and significant at $5 \%$ level suggesting that male-headed households had more income than their female counterpart. This is due to the limited access of women to productive resources such as land in lots of rural Nigerian communities and the major source of income in rural areas is from agriculture which requires land as its major input. This resulted in low income among femaleheaded households in rural areas. This corroborates the findings of Fadipe et al. (2014) and Urgessa (2015) where they reported that the gender of household heads positively influenced household income.

Household size was also positively and significantly related to household income. This suggests that household income increase as household size increases. This result is incoherent with the findings of Purnamadewi and Firdaus (2018) where they reported that household size had a negative influence on farm household income. Meanwhile, this result supports the findings of Nzabakenga et al. (2013) who reported that household size had a positive effect on rural farmers income. A positive effect of household size implies that as the household size increases the rural household annual income will increase proportionately. Considering that most rural households engaged in farming activities that are labour-intensive in developing nations, especially Nigeria, a household with a larger size will cultivate more land and increase their productivity due to the availability of cheap family labour. An increase in agricultural productivity will, in turn, increase the rural households' annual income.

Years of education was positively related to household income. This suggests that household income increases as years of education increase. This is because education improves decision making regarding the allocation of resources and production (Akanbi et al. 2020). A high level of education exposes farmers to innovative practices which make rural households head to 
Mukaila, R.; Falola, A.; Egwue, L. O. (2021). The Determinants of Rural Households' Income in Nigeria. Fiscaoeconomia, 5(3), 978-989. Doi: 10.25295/fsecon.974485

improve and increase their agricultural productivity which will result in more inflow of income to the households (Egwue et al., 2020; Obetta et al., 2020). This is in coherent with the findings of Kwaghe et al. (2009); Fadipe et al. (2014); Purnamadewi and Firdaus (2018) where they reported that the level of education increases the income in rural areas.

Table 4. The Determinants of Rural Households' Income

\begin{tabular}{|c|c|c|c|}
\hline Variables & Linear & Semi-log & Double log \\
\hline \multirow[t]{3}{*}{ Constant } & 175254.425 & $3.987104^{* * *}$ & 3.240487 \\
\hline & (51243.984) & (0.1937471) & (1.177188) \\
\hline & {$[3.42]$} & [20.58] & {$[2.75]$} \\
\hline \multirow[t]{3}{*}{ Age } & -302.216 & -0.0023151 & $0.6170751^{* *}$ \\
\hline & $(-368.556)$ & (0.0024659) & (0.2912777) \\
\hline & {$[0.82]$} & {$[-0.94]$} & [2.12] \\
\hline \multirow[t]{3}{*}{ Dependency ratio } & $-19045.32 * * *$ & $0.3642087^{* * *}$ & 0.0973004 \\
\hline & $(5119.71)$ & (0.1308403) & (1.125368) \\
\hline & {$[-3.72]$} & {$[2.78]$} & {$[0.09]$} \\
\hline \multirow[t]{3}{*}{ Gender } & $43245.241 * *$ & 0.005049 & -0.2359764 \\
\hline & $(21841.031)$ & $(0.0651797)$ & $(0.3277081)$ \\
\hline & [1.97] & [0.08] & {$[-0.72]$} \\
\hline \multirow[t]{3}{*}{ Marital status } & 4213.47 & $0.0924712^{*}$ & $-0.5531408 * * *$ \\
\hline & $(5771.877)$ & $(0.0489985)$ & (0.1820148) \\
\hline & {$[0.73]$} & [1.89] & {$[-3.04]$} \\
\hline \multirow[t]{3}{*}{ Household size } & $38105.41^{* * *}$ & م019201 & -0.0522159 \\
\hline & $(4097.356)$ & 0.0019201 & $(0.1808226)$ \\
\hline & {$[9.30]$} & $\begin{array}{l}(0.0184527) \\
{[0.10]}\end{array}$ & {$[-0.29]$} \\
\hline \multirow[t]{3}{*}{ Years of education } & $23215.142 * * *$ & $0.0156385^{* * *}$ & 0.2875691 \\
\hline & (4331.183) & $(0.0059566)$ & (1.263067) \\
\hline & {$[5.36]$} & {$[2.63]$} & {$[0.23]$} \\
\hline$R^{2}$ & 0.5213 & 0.4195 & 0.4185 \\
\hline Adjusted $\mathrm{R}^{2}$ & 0.5021 & 0.3850 & 0.3672 \\
\hline F ratio & 17.335 & 3.46 & 2.31 \\
\hline$p$-value & 0.0000 & 0.0031 & 0.0394 \\
\hline Breusch-Pagan / Cook- & $\operatorname{chi} 2(1)=0.04$ & $\operatorname{chi} 2(1)=0.40$ & $\operatorname{chi} 2(1)=0.74$ \\
\hline $\begin{array}{l}\text { Weisberg test for } \\
\text { heteroskedasticity }\end{array}$ & Prob $>$ chi2 $=0.8406$ & Prob $>$ chi2 $=0.5254$ & Prob $>$ chi2 $=0.3903$ \\
\hline
\end{tabular}

Significant at $1 \%, * *$ Significant at $5 \%, *$ Significant at $10 \%$

Source: Computed by the authors from the General Household Survey data.

\section{Conclusions}

This study investigated the factors responsible for rural households income in Nigeria. The study revealed that the rural households were characterized by large household size, high dependency ratio and a low level of education. Agricultural and allied activities play a vital role 
Mukaila, R.; Falola, A.; Egwue, L. O. (2021). The Determinants of Rural Households' Income in Nigeria. Fiscaoeconomia, 5(3), 978-989. Doi: 10.25295/fsecon.974485

in rural households as the majority of the rural household heads in Nigeria sourced their income from agricultural and allied activities. Despite their engagement in agriculture, the majority earned a monthly income lower than the minimum wage in Nigeria. This could dispose them to the incidence of poverty and low level of wellbeing. Regarding the factors influencing rural household income, the gender of the household head was positively related to household income. Similarly, a larger household size enhanced the household income in rural Nigeria. Years of education also enhanced rural household income while the dependency ratio was the only factor inhibiting the rural households' income.

To boost the income of rural people and to avoid consequences of a high rate of poverty in Nigeria and other sub-Shahara Africa including other developing nations. This study recommends encouraging rural dwellers to spend more years in school. This could be achieved through the provision of incentives such as free educational materials to them by the governments and other agencies. This would go a long way to improve their economic status which will, in turn, better their wellbeing and standard of living. Also, women empowerment through the provision of productive resources such as land and capital are important to allow them to make a significant contribution to household income.

\section{References}

Akanbi, O. S., Oloruntola, D. S., Olatunji, S. O., Mukaila, R. (2020), "Economic Analysis of Poultry Egg Production in Kwara State, Nigeria", Journal of Economics and Allied Research, 4(3), 57-71.

Anang, B. T., \& Yeboah, R. N. (2019), “Determinants of Off-Farm Income among Smallholder Rice Farmers in Northern Ghana: Application of a Double-Hurdle Model", Advances in Agriculture, 2019. https://doi.org/10.1155/2019/7246176

Beegle, K., Christiansen, L. (2019), "Accelerating poverty reduction in Africa”, Washington, DC: World Bank. (C) World https://openknowlegde.worldbank.org/handle/10986/32354 License: CC BY 3.0 IGO.

De La O Campos, A. P., Villani, C., Davis, B., Takagi, M. (2018), “Ending extreme poverty in rural areas - Sustaining livelihoods to leave no one behind", Rome, FAO. 84 pp. Licence: CC BYNC-SA 3.0 IGO.

Egwue, O. L., Agbugba, I. K., \& Mukaila, R. (2020), "Assessment of rural households food insecurity during COVID-19 pandemic in South-east Nigeria", International Journal of Research-Granthaalayah, 8(12),

182-194. https://doi.org/https://doi.org/10.29121/granthaalayah.v8.i12.2020.2713

Fadipe, A. E. A., Adenuga, A. H., \& Lawal, A. (2014), "Analysis of income determinants among rural households in Kwara State, Nigeria", Trakia Journal of Science, 12(4): 400-404. https://doi.org/10.15547/tjs.2014.04.010

Kryszak, L., Matuszczak, A. (2019), "Determinants of farm income in the European Union in new and old Member States. A Regional Study", Annals of the Polish Association of Agricultural and Agribusiness Economists, 11(3): 200-211. https://doi.org/10.5604/01.3001.0013.3042 
Mukaila, R.; Falola, A.; Egwue, L. O. (2021). The Determinants of Rural Households' Income in Nigeria. Fiscaoeconomia, 5(3), 978-989. Doi: 10.25295/fsecon.974485

Kwaghe, P. V, Ibrahim, A., Mojirode, E. A. (2009), "Socio-economic determinants of income among cowpea farmers in Bama Local Government Area of Borno State, Nigeria", Global J, Agric. Sci., 8(2): 163-167.

Mafimisebi, T. E. (2008), "Determinants and uses of farm income from the cassava enterprise in Ondo State, Nigeria", Journal of Human Ecology, 24(2): 125-130.

Mukaila, R., Falola, A., Omotesho, O. A. (2020), "Food security status: its drivers and coping strategies among vegetable farming households", Cercetări Agronomice în Moldova, 53(4), 414-425. https://doi.org/10.46909/cerce-2020-035

National Bureau of Statistics, (2020), "2019 Poverty and Inequality in Nigeria: Executive Summary". https://nigerianstat.gov.ng/download/1092 (10.02.2021)

Nzabakenga, A., Feng, L. X., Yaqin, H. (2013), "Agricultural income determinants among Smallholder Farmers : Case of Northern Part of Burundi", Asian Journal of Agriculture and Development., 3(11): 780-787.

Obetta, A. E., Mukaila, R., Onah, O. G., \& Onyia, C. C. (2020), “Challenges of Melon Processing Among Women Processors in Enugu-Ezike Agricultural Zone of Enugu State, Nigeria", Turkish Journal of Agriculture-Food Science and Technology, 8(11), 2421-2425. https://doi.org/https://doi.org/10.24925/turjaf.v8i11.2421-2425.3707

Purnamadewi, Y. L., Firdaus, M. (2018), “Analysis of income determinants among households in the upland shallot production centre in Malang district, Indonesia", 2nd International Conference on Food and Agricultural Economics, (April), 68-78. Turkey: Alanya Alaaddin Keykubat University, Turkey.

Ryś-jurek, R. (2019), "Determinants of Family Farm Income Depending on Farm Size", Annals of the Polish Association of Agricultural and Agribusiness Economists, 11(3), 401-411. https://doi.org/10.5604/01.3001.0013.4097

Safa, M. S. (2005), "Socio-Economic Factors Affecting the Income of Small-scale Agroforestry Farms in Hill Country Areas in Yemen : A Comparison of OLS and WLS Determinants", Small-Scale Forest Economics, Management and Policy, 4(1), 117-134.

Swindall, D. C. ., Willis, D. B. ., Boys, K. A., \& Hughes, D. W. (2011), "The Determinants of SelfEmployed Income in a Regional Economy", Selected Paper Prepared for Presentation at the Agricultural \& Applied Economics Association's 2011 AAEA \& NAEWA Joint Annual Meeting, Pittsburg, Pennsylvania, July 24-26, 1-22.

Urgessa, T. (2015), "The determinants of agricultural productivity and rural household income in Ethiopia", Ethiopian Journal of Economics., 14(2): 63-92.

Usman, Z.A., Ritter K., Vinogradov S.A. (2016), "The Dynamics of Income Inequality in Rural Areas of Nigeria", Asian Journal of Agricultural Extension, Economics. \& Sociology, 11(4): 1-13.

Viera, W., Viera, A., Martínez, A., Jácome, R., Ayala, G., Sotomayora, A., Galarzaa, D., Ron, L. (2017), "Factors influencing peach farmer income in the province of Tungurahua, Ecuador", Economía Agraria y Recursos Naturales, 17(2), 133-141. 
Mukaila, R.; Falola, A.; Egwue, L. O. (2021). The Determinants of Rural Households' Income in Nigeria. Fiscaoeconomia, 5(3), 978-989. Doi: 10.25295/fsecon.974485

World Bank (2018), "Year in Review: 2018 in 14 Charts".

https://www.worldbank.org/en/news/feature/2018/12/21/year-in-review-2018-in-14charts (10.09.2020).

World Bank (2019), "Nigeria At-A-Glance". https://www.worldbank.org/en/country/nigeria (10.09.2020).

Xiong, Z., Niu, Y. (2010), "Factors affecting the income of farmers", Asian Agricultural Research, 2(5): 18-20, 26.

Ethics Statement: The authors declare that ethical rules are followed in all preparation processes of this study. In case of detection of a contrary situation, Fiscaoeconomia has no responsibility and all responsibility belongs to the authors of the study.

Author Contributions: Ridwan Mukaila contributed to the study in Introduction, Theoretical Framework and Empirical Literature sections, data collection stages, Econometric Methodology and results sections, Conclusion. Abraham Falola contributed to the study in the Introduction, Data Set, Econometric Methodology and Results sections, in the data collection and analysis stages. Lynda Ogechi Egwue Abraham Falola contributed to the study in the Introduction, Data Set, Econometric Methodology and Results sections, in the data collection and analysis stages. 1st author's contribution rate: $40 \%, 2$ nd author's contribution rate: $30 \%$, 3rd author's contribution rate: $30 \%$.

Conflict of Interest: There is no conflict of interest between the authors. Acknowledgment: Not application 